\title{
Natural ageing of polyaramide fiber from ballistic armor
}

\author{
Vitor Hugo Cordeiro Konarzewski ${ }^{*}$ (D), Fernando Ludgero Spiekemann ${ }^{1}$ and \\ Ruth Marlene Campomanes Santana ${ }^{1}$
}

\author{
'Laboratório de Polímeros - LAPOL, Universidade Federal do Rio Grande do Sul - UFRGS, \\ Porto Alegre, RS, Brasil \\ *vitorhk@sinos.net
}

\begin{abstract}
Ballistic armor has been manufactured primarily based on polyaramide (Kevlar and Twaron) or Dyneema but the lifespan warranty in Brazil is only 5 years and after this time period they are incinerated or comminuted and ground up. This study aims to evaluate the changes on the physical, mechanical and morphological properties of polyaramide fibers of ballistic armor after natural aging. These samples with different fabrication (2005 and 2010) and usage time were exposed to natural weathering in the city of Porto Alegre, southern Brazil, during the period of one year. Morphology fiber results surfaced after ageing, it showed fiber swelling, stress cracking and defibrillation, and the results of the mechanical tensile testing of the polyaramide fibers showed a pronounced decrease $(80 \%)$ in tensile strength. It can be concluded that the weight, the dtex of the fiber and the kind of fabric can influence the degradation degree under natural exposure.
\end{abstract}

Keywords: ballistic armor, aramid fibers, polymer degradation.

How to cite: Konarzewski, V. H. C., Spiekemann, F. L., \& Santana, R. M. C. (2019). Natural ageing of polyaramide fiber from ballistic armor. Polímeros: Ciência e Tecnologia, 29(1), e2019002. https://doi.org/10.1590/0104-1428.05617

\section{Introduction}

The ballistic armor market in Brazil is approximately one million users, who act directly in police actions and other inherent activities ${ }^{[1,2]}$. With an expiration date of five years from the date of manufacture, the legislation in Brazil determines the destruction of the material by shredding or incineration after the theoretical expiry date, without taking into account the commercial value of the polyaramide or the stability of the raw material ${ }^{[3-5]}$. The use of lightweight ballistic vests was increased after the 1960s with the development of high-performance aramid fibers, or poly ( $p$-phenylene terephthalamide), referred to as Kevlar by DuPont, registered in $1971^{[6]}$. Another registered polyaramide trademark of Teijin, Twaron, whose properties of heat resistance, flexibility, dimensional stability and high mechanical resistance have made the polyaramide fibers quickly gain space in the most demanding industrial applications and also in the security area, being subject to constant study and improvement for use in ballistic armor ${ }^{[7-9]}$. There are usually two basic characteristics that respond to the trust placed in the aramid shield until now: the chemical composition of the fiber and the way the yarns are woven and interlaced in multilayers. Under the impact of the projectile, the energy is dissipated through the panel, by friction, absorption and dissipation of the shock waves avoiding perforation ${ }^{[10-17]}$. The aromatic polyamides were obtained by reactions that lead to the formation of amide bonds between aromatic rings of high thermal stability and high strength ${ }^{[18-21]}$. The exceptionally rigid molecular chain structure, good orientation and organization of the crystalline structure provides high strength and low elongation of the orientation of the molecular chains, offering high tensile strength, impact and with differentiated thermal stability for various temperature ranges for an extended time ${ }^{[22-25]}$.

The susceptibility of aramid fibers exposed to light and moisture is confirmed by several researchers, such as Bittencourt ${ }^{[12]}$, Wang et al. ${ }^{[26]}$ and De Paoli ${ }^{[27]}$, among other authors. These works describe the fiber surface and the photo degradation process, which gradually reduces its molar mass, mainly due to oxidation and the splitting of the amide group. Another factor that may influence the degradation is the presence of impurities in the fiber due to the weakening of the structure by the formation of free radicals and causing the polymer chains to break up, which characterizes the hydrolytic degradation of the polyaramide fibers ${ }^{[28-33]}$. The absorption of humidity together with the presence of oxygen and moisture can produce molecular reorganization, from the breakdown of a molecular chain to its oxidation ${ }^{[9,34]}$. Another factor that may influence the polymer life cycle is related to the effect of stress cracking, which may influence the macroscopic properties of the tissues, such as the weave and warp of the fabric ${ }^{[35,36]}$. The degradation process may also cause changes in the properties of the polyaramide, such as loss of brightness, changes in color, cracking and the decrease of mechanical properties ${ }^{[26,37]}$. The blades of armor are not exposed directly to solar radiation, nor direct exposure to weathering, since the blades are arranged in layers, coated by at least two additional layers of different impermeable fabrics ${ }^{[1,38]}$.

In this sense, the objective of this study is to evaluate the loss of the mechanical properties of polyaramide fibers 
used as raw material for the manufacture of ballistic armor with different dates of manufacture and use after exposure to natural weathering.

\section{Materials and Methods}

\subsection{Material}

The polyaramide fibers came from tissues samples of ballistic armor that was more than 5 years old, that had been disposed of by the logistic center of the Brigada Militar of the State of Rio Grande do Sul. The fiber samples had a dtex of 1670 (2010 - unused vest) and 933 (2005, for a vest that was normally used for five years), referred to as K10 and K05 respectively. The fabrics were trimmed into squares sized $100 \mathrm{~mm} \times 100 \mathrm{~mm}$, and were exposed to natural weathering following ASTM standard ${ }^{[39-41]}$. The main characteristics of the fibers used for the tensile test are summarized in Table 1 and Figure 1 showing the difference of the weave of the polyaramide fabric samples from 2005 (left) and 2010 (right) fabrics.

\subsection{Exposure to natural ageing}

The specimens tested $(100 \mathrm{~mm} \times 100 \mathrm{~mm})$ were exposed to weathering for 12 months (from February 2014 to February 2015), under real climatic conditions in accordance with ASTM 1435-13. Specimens tests were exposed to natural sunlight outdoors in northern direction at $45^{\circ}$ inclination as can be seen in Figure 1.

The geographical location of the samples was latitude $\left(30^{\circ} 05^{\prime}\right.$ South), longitude ( $51^{\circ} 11^{\prime}$ 'West), and altitude $(174 \mathrm{~m})$ in the city of Porto Alegre, in the south of Brazil. This allowed for a normal incidence of solar radiation over the entire surface of the samples. During the natural weathering test it was monitored the average UV radiation index, temperature, and the rainfall that was provided by the CPTED-INPE (Center for weather and climate studies - National Institute for Space Research - Brazil). Figure 2 shows the climatic conditions (maximum Precipitation and

Table 1. Characteristics of the polyaramide fibers.

\begin{tabular}{ccc}
\hline Sample & K05 & K10 \\
\hline Denier & 840 & 1500 \\
Dtex & 933 & 1670 \\
Warrantee* $^{*}$ & 2010 & 2015 \\
\hline
\end{tabular}

*Warrantee given by the armor manufacturers.

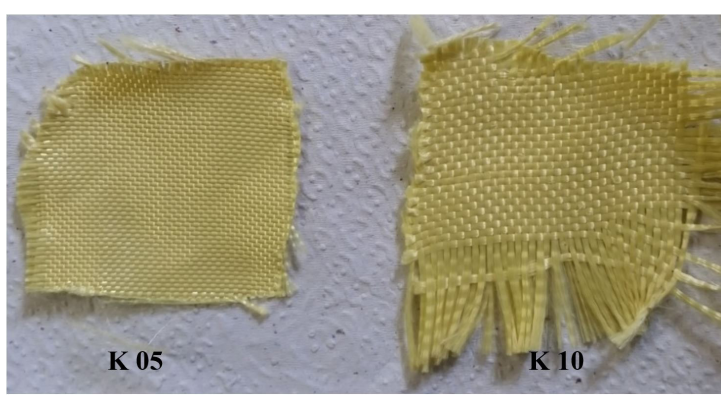

Figure 1. Samples from armor fabrics used in this research. maximum UV index (UVI), moisture and average total monthly rainfall) during the total period studied.

It was observed that the highest temperatures occurred during the months of November 2014 to March 2015, but the maximum temperature in January 2015, which reached over 2014 to January 2015, and between September 2014 to January 2015 the frequency of rainfall was higher, reaching $778 \mathrm{~mm}$ values. As a result, the relative humidity was high during this period, between 70 to $90 \%$. Regarding the UVI, the values were high during the spring and summer, reaching values over 12, which is classified as extreme.

\subsection{Colorimetric and optic analysis}

The surface color of the polyaramide samples (every two months) were measured using a Spectro-Guide spectrophotometer, BYK, in accordance with ASTM D2244. Spectrometer's Spectro-Guide software transforms spectral data into CIELAB color coordinates ( $\mathrm{L}^{*}, \mathrm{a}^{*}$, and $\mathrm{b}^{*}$ ) based on a D65 light source. Lightness $\left(\mathrm{L}^{*}\right)$ and two chromaticity coordinates $\left(\mathrm{a}^{*}\right.$ and $\left.\mathrm{b}^{*}\right)$ were measured at three different positions on each sample. In addition, the gloss $(\mathrm{G})$ of the samples was measured. An increase in $L^{*}$ value means the color of the sample becomes lighter. A positive $a^{*}$ signifies a color shift towards red, and a negative $\mathrm{a}^{*}$ signifies a color shift towards green. A positive $b^{*}$ signifies a shift towards yellow, and a negative $b^{*}$ signifies a shift towards blue.

\subsection{Tensile test}

The fiber tensile test was performed on the INSTRON 3382 universal testing machine based on ASTM D7269M-11 ${ }^{[42]}$. By limiting the length of the fibers to $100 \mathrm{~mm}$, it was opted for the D3822M-14 standard ${ }^{[43]}$. As can be observed in Figure 3, the fibers were glued on to a cardboard base, with a grammage of $180 \mathrm{~g} . \mathrm{m}^{-2}$ and dimensions of $2 \times 5 \mathrm{~mm}$, being cast to the center with a diameter of $9 \mathrm{~mm}$. Tensile tests of polyaramide fibers were carried out according to ASTM D3822M-14 in a universal test machine using specimens tested with a length of $100 \mathrm{~mm}$ and a load cell of $1000 \mathrm{~N}$, an extension speed of $5 \mathrm{~mm} \mathrm{~min}^{-1}$, and a gauge length of $25 \mathrm{~mm}$. Each tensile value reported is the average of a 10 specimen test.

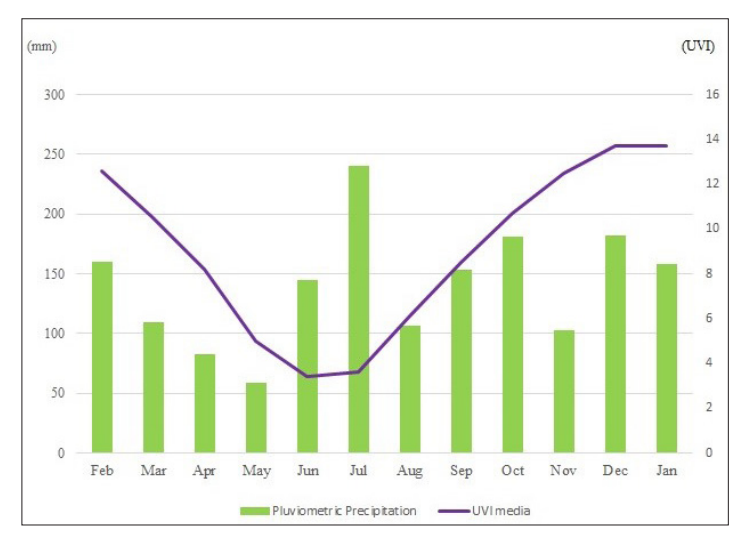

Figure 2. Climatic precipitation and Ultraviolet Index (UVI) in the city of Porto Alegre (2014-2015). 


\subsection{Morphologic analysis, SEM}

For the scanning electron microscopy (SEM) analysis, the samples were deposited in a carbon type stuck to stub, metalized with gold. For image acquisition, a SEM model JOEL 6060 was used with $2 \mathrm{kV}$ and magnification of $1000 \mathrm{x}^{[44]}$.

\subsection{Diameter calculation of the polyaramide fiber}

For the calculation of the polyaramide fiber diameters a 50 micron scale was used and based on the image it was divided into an area of nine equal divisions containing a significant amount of fibers for analysis, the average was

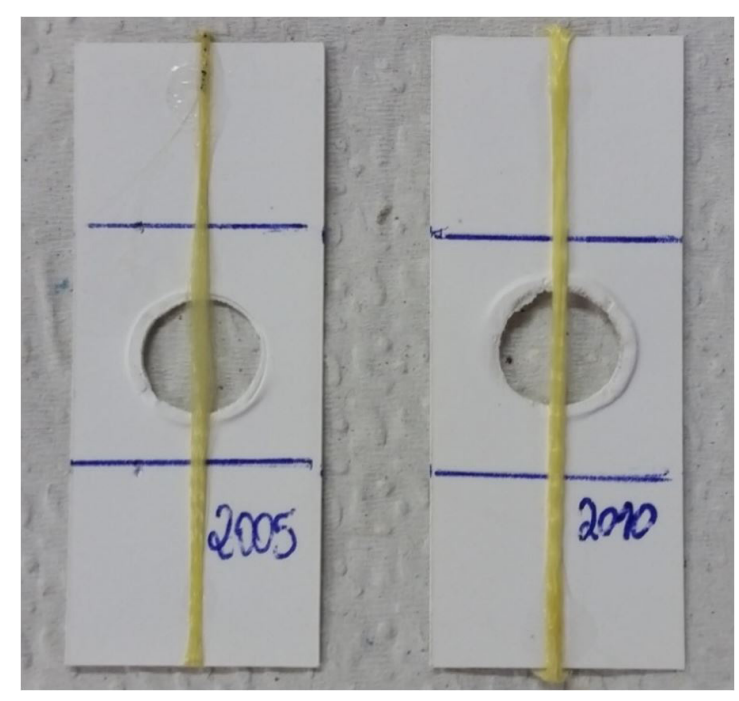

Figure 3. Specimen test preparation for tensile test. obtained. Within each area, the amount of fibers "j" were counted, obtaining the same diameter as "fj". With both of the samples, the average of the area "Zi" was obtained. The procedure was repeated in the delimited areas, and the mean diameter was calculated. The advantage of this method was the correct division of the zones with a low error in the diameter estimation, with two weights, considerably reducing the error.

\section{Results and Discussions}

\subsection{Colorimetric and optical proprieties}

Figure 4 shows the results of the colorimetric parameters of the polyaramide $\mathrm{K} 05$ and $\mathrm{K} 10$ samples before and after exposure to natural weathering. The most significant change in color with a tendency to darken the samples from yellow to a darker shade occurred in the first two months of exposure, with a reddish tendency due to the increase of parameter " $+\mathrm{a}$ " to positive values, changes that can be better visualized in Figure 5, with woven samples before and after exposure. In addition, a reduction of parameter " $\mathrm{b}$ "” lower yellowness was observed, because of the increase the redness $(+a)$ of the sample. These color changes indicate chain cleavage due to the hydrolytic degradation of the polyamides.

Such photo degradation features are reported by Bittencourt $^{[12]}$ and Billingham ${ }^{[34]}$, describing the degradation processes of the polyaramide fibers. The change of coloration, as well as the loss of brightness, represented by the decrease of Luminosity (c) (the fiber became more opaque) and increase of fiber roughness. The decrease of the Gloss (d), can be attributed to hydrolysis too, in addition to this, there was environmental stress cracking too, due to the climatic

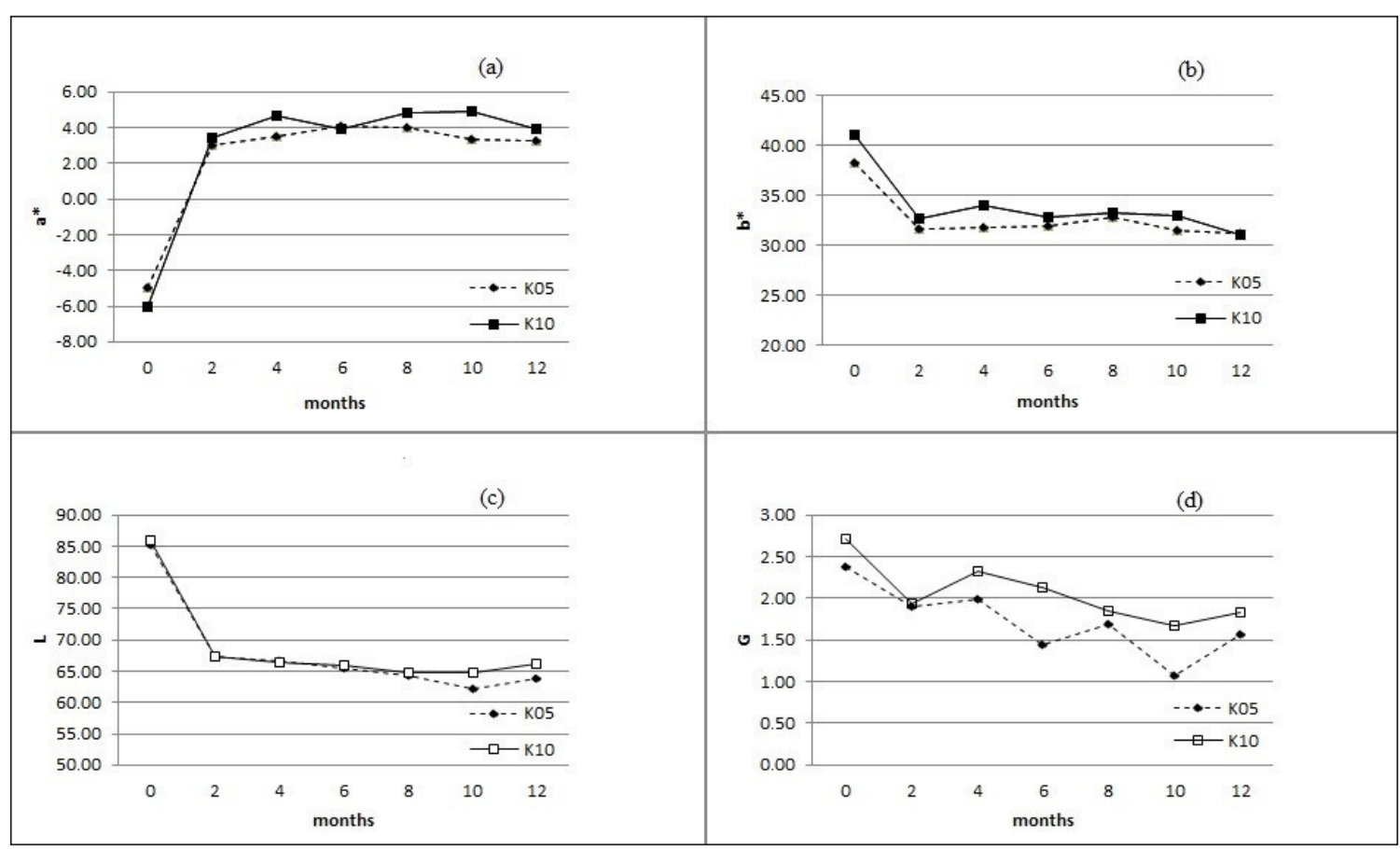

Figure 4. Colorimetric and optical results of the samples before and after natural ageing: (a) parameter "a"; (b) parameter "b"; (c) Luminosity; and (d) gloss. 
conditions to which they were exposed, greater periods of precipitation and temperature variations, which depleted the fibers, being faster in samples $\mathrm{k} 10$. The signs of degradation reached the superficial layers of the tissues, causing an initial discoloration, facts reported by Wang et al. ${ }^{[26]}$ and De Paoli ${ }^{[27]}$. The initial colorimetric results of the degradation of the samples were very similar for the K05 and K10 samples. However, due to the difference in the fabric weaving and the yarn, after two months of continuous exposure to the

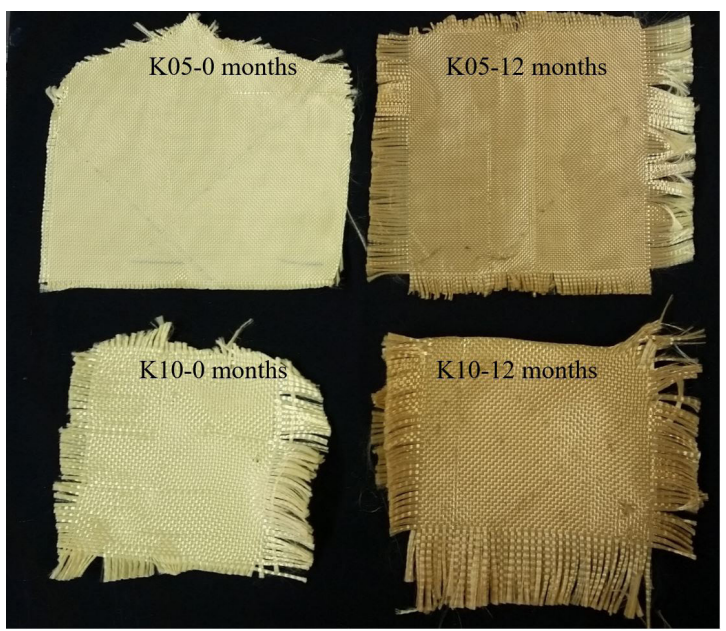

Figure 5. Color changes of the samples before and after natural ageing.
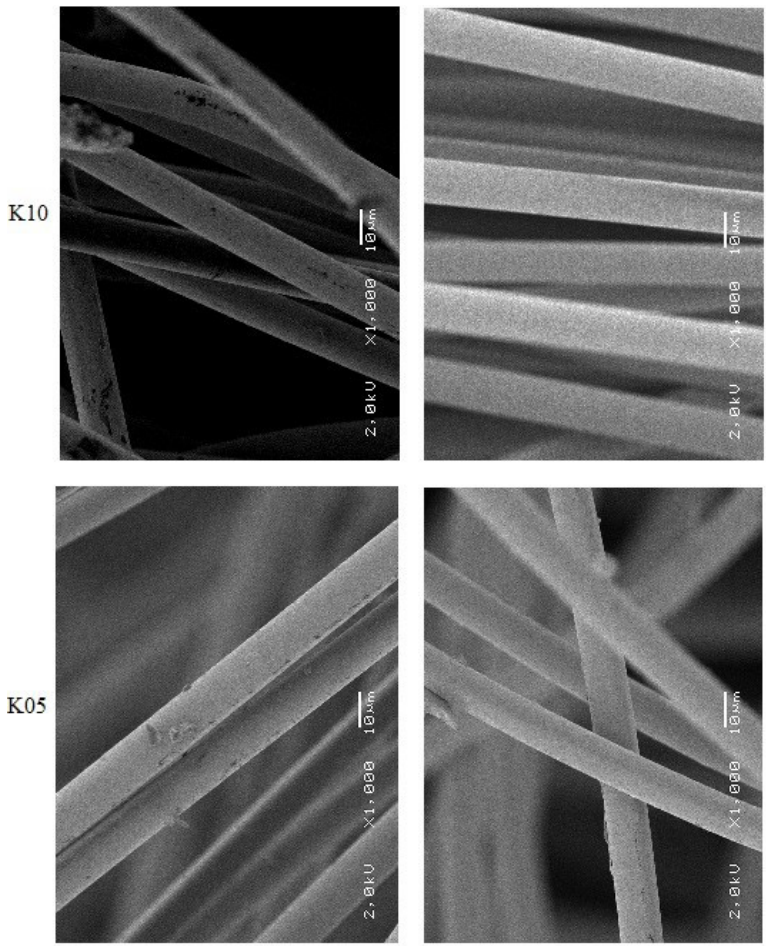

0 months

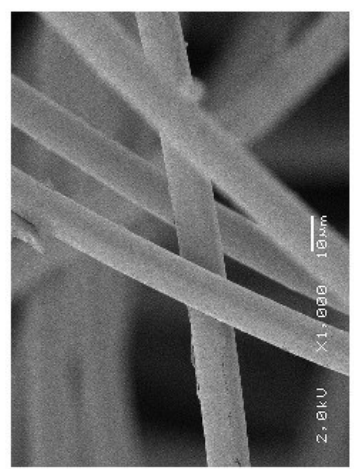

4 months weather, it was observed that the brightness indicators related to the roughness were not uniform. Such signs may indicate a fiber degradation process, which is directly related to the exposure area, as well as the interlacing of the threads.

\subsection{Morphological properties, SEM}

Figure 6 shows the micrographs of the polyaramide fibers of samples K05 and K10 before and after exposure to natural weathering. It was possible to verify that both of them presented a clean and regular surface before exposure, but after four months it was observed that the fibers K 05 presented less aggression on their surface when compared to the fibers K10, this was probably influenced by the type of weave, weight and lower dtex as shown in Table 1. The degradation of the samples after exposure to natural weathering is related to $\mathrm{UV}$ radiation, acid rain and impurities, which under temperatures ranging between 3 to $40^{\circ} \mathrm{C}$ altered the fibers over a year. The increase of striations and surface deformations can be attributed to hydrolysis, stress cracking as well as UV radiation, with morphological changes being evident visually similar to the two aramid samples ${ }^{[26,27]}$. For the initial sample, without exposure to the $\mathrm{k} 05$ and K10, no signs of premature wear of the samples were observed. Such morphology denotes the stability of the fiber, since it is not exposed to light effects ${ }^{[33,36]}$. These effects were observed with the progressive appearance of striations, roughness, surface defects and incrustations, indicating the progressive degradation of the fiber ${ }^{[36,37]}$. After four months the morphological changes became more visible, with the appearance of cracks showing a few obvious signs of fiber
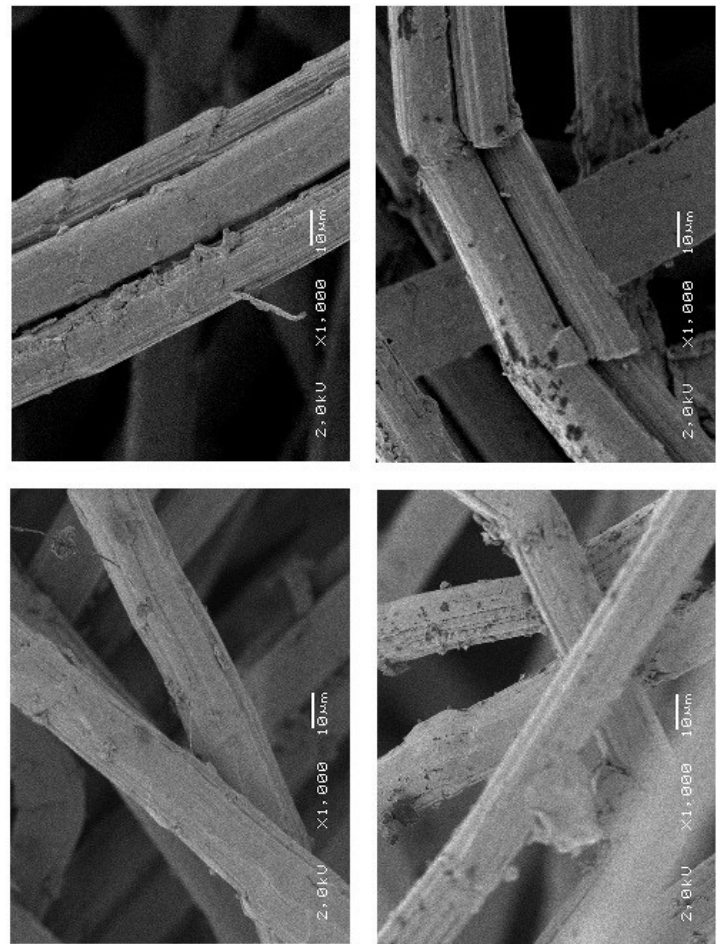

8 months

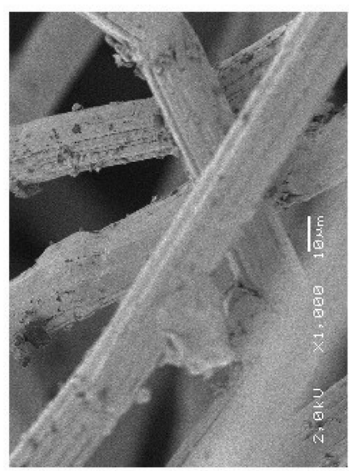

12 months

Figure 6. MEV from samples K05 and K10 before and after natural ageing. 
degradation, especially in the K10 sample, which despite having a larger dtex, had a more open tissue weave.

Photo degradation was more severe with the more open frame, exposing the samples to light and humidity, increasing photochemical degradation, hydrolysis and stress-cracking ${ }^{[27,30,31]}$. The variation of fiber diameters during one year, as shown in Figure 7, caused a light increase of the diameter of the aramid fibers of sample K10, when compared to sample $\mathrm{k} 05$.

Comparing the sample $\mathrm{K} 10$ with $\mathrm{K} 05$, from a ballistic vest used over 5 years, it was observed that the diameter of the fibers is very similar in the initial sample " 0 months", not presenting high degradation or absorption of significant humidity over five years of sample difference ${ }^{[12,39]}$. With the exposure time, the K 05 sample presented a slightly lower humidity absorption over the period of one year, however an increase of the sample diameter occurred, caused by hydrolysis degradation. The initial diameter of the fibers corresponds to that reported by other researchers when characterizing the diameter of the polyaramide fibers 49 , around $12 \mu \mathrm{m}$, for new fibers ${ }^{[6,20,22]}$. These results reinforce the hypothesis of fiber stability, even after five years of use (before natural ageing), maintaining similar morphological characteristics as when it was new, thanks to the protective cover of the ballistic panels, avoiding direct exposure to the sun or hydrolysis of the fiber.

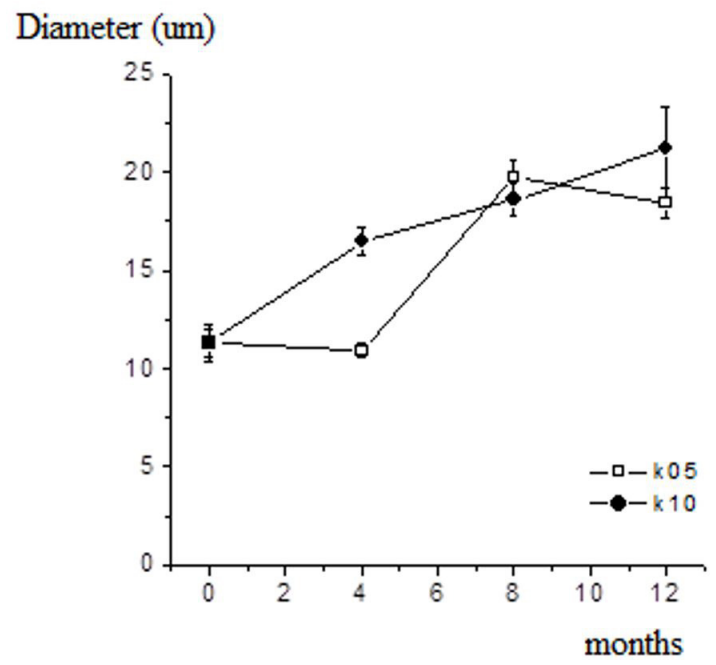

Figure 7. Diameter changes of polyaramide fiber after natural ageing.

\subsection{Mechanical properties}

Table 2 shows the average results of the maximum tensile stress of fibers $\mathrm{K} 05$ and $\mathrm{K} 10$ before and after exposure to natural weathering. Comparing the initial results, the polyaramide fiber presented good stability, even considering the time of use, storage and the fact that the samples $\mathrm{k} 05$ and $\mathrm{K} 10$ were removed from fabrics, theoretically subjected to mechanical degradation in function of the weaving ${ }^{[1,23,30]}$. Table 2 also summarizes the mechanical properties of maximum stress until fiber rupture and elongation, in $\mathrm{mN} /$ tex, recorded during the tensile test. Considering the difference of origin of the fibers, it was decided to compare the data in $\mathrm{mN} /$ tex, and it was possible to verify the reduction of strength force and elasticity over a year ${ }^{[16,26,30]}$. The hydrolysis, stress-cracking environment and photo degradation mechanisms present on the fibers degradation process were more accentuated in the first 60 days, remaining stable for two months with resistance decline and reduced after 6 months.

As can be seen in Figure 8, the major change occurred after two months, when K10 fiber presented only $52 \%$ of the maximum stress until rupture and the sample K05 34\%, proving the loss of properties of the polyaramide when submitted to natural ageing.

The initial reduction of resistance of samples k10 and k05 can be attributed to the amount of fibers and the stress-cracking environment, hydrolysis and photo degradation, since the sample $\mathrm{k} 10$ had a higher amount of fibers when compared to sample K05, which when exposed to the weather were affected from the outside to the inside ${ }^{[31]}$. From the fourth month of exposure until the sixth month, the sample $\mathrm{k} 10$ had a more pronounced loss of strength, after that the samples started to have a similar resistance decrease, reaching $18 \%$ of the original resistance of the yarns in 12 Months of exposure ${ }^{[22,26,38]}$.

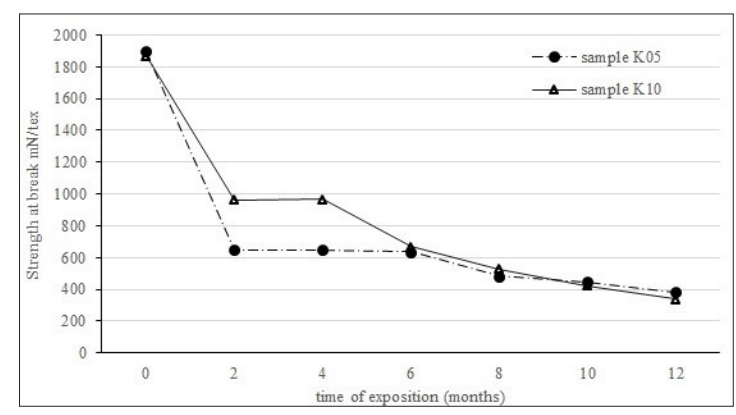

Figure 8. Maximum tension from polyaramide by natural ageing (mN/dtex).

Table 2. Mechanical proprieties of polyaramide fibers

\begin{tabular}{|c|c|c|c|c|}
\hline \multirow{2}{*}{$\begin{array}{l}\text { Exposition time } \\
\text { (months) }\end{array}$} & \multicolumn{2}{|c|}{ Breaking strength (mN/tex) } & \multicolumn{2}{|c|}{ Elongation at break (\%) } \\
\hline & K 2005 & K 2010 & K 2005 & K 2010 \\
\hline 0 & $1898 \pm 159.4$ & $1870 \pm 95.2$ & 6.0 & 7.0 \\
\hline 2 & $649 \pm 134.3$ & $964 \pm 180.5$ & 5.0 & 5.0 \\
\hline 4 & $650 \pm 57.2$ & $968 \pm 118.4$ & 4.0 & 5.0 \\
\hline 6 & $637 \pm 151.4$ & $667 \pm 85.6$ & 3.8 & 4.0 \\
\hline 8 & $483 \pm 115.7$ & $526 \pm 31.7$ & 3.0 & 3.3 \\
\hline 10 & $445 \pm 88.4$ & $422 \pm 54.7$ & 2.0 & 2.7 \\
\hline 12 & $382 \pm 63.3$ & $339 \pm 23.3$ & 3.0 & 2.3 \\
\hline
\end{tabular}




\section{Conclusions}

Results of this study showed that new or used polyaramide blankets (before exposure to natural weathering) did not present colorimetric, optical or mechanical changes. However, after exposure to natural weathering for a total period of one year, in the city of Porto Alegre, RS, Brazil, they showed a pronounced color change and a considerable loss in the mechanical performance of the fibers during the first 2 months. Highlighting the largest changes in K10 samples, although this has never been used, but with different weft and dtex from the sample used for 5 years K05a. K05 samples showed higher mechanical performance and lower swelling and less aggression from environmental stress-cracking in the first 2 months. Finally, it is concluded that all samples analyzed after exposure to natural weathering presented hydrolytic degradation, environmental stress-cracking and photochemistry.

\section{Acknowledgements}

The authors would like to thank LAPOL of the Federal University of Rio Grande do Sul and the Brigada Militar of the State of Rio Grande do Sul for the materials and support provided for the development of this study.

\section{References}

1. Companhia Brasileira de Cartuchos-CBC. (2017, March 16). Coletes balísticos. Retrieved in 2017, September 8, from http:// www.cbc.com.br/coletes-balisticos-subcat-29.html\#aramida

2. Brasil. Ministério da Ciência, Tecnologia, Inovações e Comunicações. Centro de Gestão e Estudos Estratégicos. (2010). Materiais avançados: 2010-2022. Brasília: MCTI.

3. Brasil. Ministério da Defesa. Exército Brasileiro. (2006, February 23). Portaria $n^{\circ} 18$ - D LOG. Aprova as normas reguladoras da avaliação técnica, fabricação, aquisição, importação e destruição de coletes à prova de balas. Diário Oficial da República Federativa do Brasil, Brasil.

4. Brasil. Ministério da Defesa. Exército Brasileiro. (2015). Relatório do comando de operações terrestres. Brasília: Ministério da Defesa.

5. Brigada Militar. (2006). Norma de instrução operacional $n^{o}$ 17. Porto Alegre: EMBM.

6. Rebouillat, S. (2001). Aramids. In J. W. S. Hearle (Ed.), Highperformance fibres (pp. 31-69). England: Woodhead Publishing.

7. Askeland, D. R., \& Jones, D. R. H. (1998). The science and engineering of materials (3rd ed.). Columbia: University of Missouri.

8. Mano, E. B. (2011). Polímeros como materiais de engenharia. São Paulo: Blücher.

9. Canevarolo, S. V., Jr. (2010). Ciência dos polímeros: um texto básico para tecnólogos e engenheiros. São Paulo: Artiber.

10. Bandaru, A. K., Vetiyatil, L., \& Ahmad, S. (2015). The effect of hybridization on the ballistic impact behavior of hybrid composite armors. Composites. Part B, Engineering, 76, 300319. http://dx.doi.org/10.1016/j.compositesb.2015.03.012.

11. Allen, S. R., \& Roche, E. J. (1989). Deformation behaviour of Kevlar ${ }^{\circledR}$ aramid fibres. Polymer, 30(6), 996-1003. http:// dx.doi.org/10.1016/0032-3861(89)90069-4.

12. Bittencourt, G. A. (2011). Efeito da radiação gama em blindagens balísticas compósitas de poliaramida (Master's thesis). Instituto Militar de Engenharia, Rio de Janeiro.
13. Bendada, A., Sfarra, S., Genest, M., Paoletti, D., Rott, S., Talmy, E., Ibarra-Castanedo, C., \& Maldague, X. (2013). How to reveal sussurface defects in kevlar composite materials after an impact loading using infrared vision and optical NDT techniques. Engineering Fracture Mechanics, 108, 195-208. http://dx.doi.org/10.1016/j.engfracmech.2013.02.030.

14. Assis, F. S. (2016). Comportamento balístico de blindagem multicamadas com compósitos de poliéster reforçados com fibras de juta (Master's thesis). Instituto Militar de Engenharia, Rio de Janeiro.

15. Saijo, K., Arimoto, O., Hashimoto, T., Fukuda, M., \& Kawai, H. (1994). Moistures sorption mechanism of aromatic polyamide fibers: diffusion of moistures into regular Kevlar as observed by time resolved small angle $\mathrm{X}$ ray scattering technique. Polymer, 35(3), 496-503. http://dx.doi.org/10.1016/00323861(94)90502-9.

16. Bourbigot, S., Flambard, X., \& Poutch, F. (2001). Study of thermal degradation of high performance fibers-application to polybenzazole and p-aramide fibers. Polymer Degradation \& Stability, 74(2), 283-290. http://dx.doi.org/10.1016/S01413910(01)00159-8.

17. Yang, H. H. (1993). Kevlar aramid fiber. Chichester: John Wiley \& Sons.

18. Hearle, J. W. S. (2001). High-performance fibers. Boca Raton: CRC Press.

19. Callister, W. D., Jr. (2002). Ciência e engenharia de materiais: uma introdução. Rio de Janeiro: LTC.

20. Rebouillat, S., Peng, J. C. M., \& Donnet, J.-B. (1999). Surface structure of Kevlar fiber studie by atomic force microscopy and inverse gas cromatography. Polymer, 40(26), 7341-7350. http://dx.doi.org/10.1016/S0032-3861(99)00040-3.

21. Bencomo-Cisneros, J. A., Tejeda-Ochoa, A., García-Estrada, J. A., Herrera-Ramírez, C. A., Hurtado-Macías, A., MartínezSánchez, R., \& Herrera-Ramírez, J. M. (2012). Characterization of Kevlar-29 fibers by tensile tests and nanoindentation. Journal of Alloys and Compounds, 536(Suppl 1), S456-S459. http:// dx.doi.org/10.1016/j.jallcom.2011.11.031.

22. DuPont. (2010). Manual técnico Kevlar ${ }^{\circledR}$ fibra de aramida. São Paulo: DuPont Advanced Fibers Systems.

23. Aguiar, P. P. N. (1996). Fibras têxteis. Rio de Janeiro: SENAIDN

24. Pardini, L. C., \& Levy, F. N. (2006). Compósitos estruturais: ciência e tecnologia. São Paulo: Blücher.

25. Lin, T., Wu, S., Lai, J., \& Shyu, S. (2000). The effect of chemical treatment on reinforcement/matrix interactions in Kevlar-fiber/bismaleimide composites. Composites Science and Technology, 60(9), 1873-1878. http://dx.doi.org/10.1016/ S0266-3538(00)00074-9.

26. Wang, H., Xie, H., Hu, Z., Wu, D., \& Chen, P. (2012). The influence of UV radiation and moisture on the mechanical properties and micro-structure of single Kevlar fibre using optical methods. Polymer Degradation \& Stability, 97(9), 1755-1761. http://dx.doi.org/10.1016/j.polymdegradstab.2012.06.010.

27. De Paoli, M. A. (2008). Degradação e estabilização de polímeros. São Paulo: Artliber.

28. Santos, A. S. F., Agnelli, J. A. M., Trevisan, D. W., \& Manrich, S. (2002). Degradation and stabilization of polyolefin from municipal plastics waste during multiple extrusions under different eprocessing conditions. Polymer Degradation \& Stability, 77(3), 441-447. http://dx.doi.org/10.1016/S01413910(02)00101-5.

29. Bertin, D. M., Larissa, S., Catto, A. L., Camargo, M. M. F., Chiellini, E., Corti, A., Morelli, A., \& Campomanes, R. M. S. (2010). Polypropylene degradation: theoretical and experimental investigation. Polymer Degradation \& Stability, 95(5), 186-192. http://dx.doi.org/10.1016/j.polymdegradstab.2010.02.006. 
30. Arrieta, C., David, E., Dolez, P., \& Vu-Khanh, T. (2011). Hydrolytic and photochemical aging studies of a Kevlar ${ }^{\circledR}-\mathrm{PBI}$ blend. Polymer Degradation \& Stability, 96(8), 1411-1419. http://dx.doi.org/10.1016/j.polymdegradstab.2011.05.015.

31. American Society for Testing and Materials-ASTM. (1996). ASTM G 53-96: operating light and water-exposure apparatus (fluorescent $U V$-condensation type) for exposure of nonmetallic materials. West Conshohocken: ASTM International.

32. Ashby, M. F., \& Jones, D. R. H. (2007). Engenharia de materiais. Rio de Janeiro: Elsevier.

33. Morgan, R. J., \& Pruneda, C. O. (1987). The caracterization of the chemical impurities in Kevlar 49 fibers. Polymer, 28(2), 340-346. http://dx.doi.org/10.1016/0032-3861(87)90428-9.

34. Billingham, N. C. (2002). Fundamentals of degradation and stabilizations of polymers. In F. La Mantia (Ed.), Handbook of plastic recycling (pp. 23-64). Shrewsbury: Rapra Technology.

35. Zhang, H. T. (2010). Comparison and analysis of thermal degradation process of aramid fibers. Journal of Fiber Bioengineering and Informatics, 3(3), 163-167. http://dx.doi. org/10.3993/jfbi12201008.

36. Zhu, F. L., Feng, Q. Q., Xin, Q., \& Zhou, Y. (2014). Thermal degradation process os polysulphone aramid fiber. Thermal Science, 18(5), 1637-1641. http://dx.doi.org/10.2298/ TSCI1405637Z.

37. Rosa, D. S., \& Filho, R. P. (2003). Biodegradação: um ensaio com polímeros. São Paulo: Moara.

38. Wan, Y. Z., Wang, Y. L., Huang, Y., Luo, H. L., He, F., \& Chen, G. C. (2006). Moisture absorption in a three dimensional braided
carbon/Kevlar/epoxy hybrid composite for orthopaedic usage and its influence on mechanical performance. Composites. Part A, Applied Science and Manufacturing, 37(9), 1480-1484. http://dx.doi.org/10.1016/j.compositesa.2005.09.009.

39. Dupont. (2015, 3 February). Technical guide Kevlar: Kevlar ${ }^{\circledR}$ properties. Retrieved in 2017, September 8, from http://www2. dupont.com/Kevlar/en_US/assets/downloads/KEVLAR_ Technical_Guide.pdf

40. Teijin. (2017, 3 February). Teijin aramid ballistics material handbook. Retrieved in 2017, September 8, from http://www. teijinaramid.com/wp-content/uploads/2016/05/Teijin-AramidBallistics-Material-Handbook.pdf

41. American Society for Testing and Materials-ASTM. (2013). ASTM D1435-13: standard pratice for outdor weathering of plastics. West Conshohocken: ASTM International.

42. American Society for Testing and Materials-ASTM. (2011). ASTM D7269M-11: standard test methods for tensile testing of aramid yarns. West Conshohocken: ASTM International.

43. American Society for Testing and Materials-ASTM. (2014). ASTM D3822M-14: standard test method for tensile poperties of single textile fibers. West Conshohocken: ASTM International.

44. Holler, F. J., Skoog, D. A., \& Crouch, S. R. (2009). Princípios de análise instrumental. Porto Alegre: Bookman.

Received: Sept. 08, 2017 Revised: May 24, 2018 Accepted: May 25, 2018 